\title{
Structure and Electrical Properties of $\mathrm{Fe}_{2} \mathrm{O}_{3}$-Doped PZT-PZN-PMnN Ceramics
}

\author{
Le Dai Vuong1,2*, Phan Dinh Gio1 \\ ${ }^{1}$ Department of Physics, College of Sciences, Hue University, Hue City, Vietnam \\ ${ }^{2}$ Faculty of Chemical and Environmental Engineering, Hue Industry College, Hue City, Vietnam \\ Email: ledaivuongab@gmail.com
}

Received 9 May 2014; revised 7 June 2014; accepted 2 July 2014

Copyright (C) 2014 by authors and Scientific Research Publishing Inc.

This work is licensed under the Creative Commons Attribution International License (CC BY). http://creativecommons.org/licenses/by/4.0/

(c) (i) Open Access

\section{Abstract}

The $0.8 \mathrm{~Pb}\left(\mathrm{Zr}_{0.48} \mathrm{Ti}_{0.52}\right) \mathrm{O}_{3}-0.125 \mathrm{~Pb}\left(\mathrm{Zn}_{1 / 3} \mathrm{Nb}_{2 / 3}\right) \mathrm{O}_{3}-0.075 \mathrm{~Pb}\left(\mathrm{Mn}_{1 / 3} \mathrm{Nb}_{2 / 3}\right) \mathrm{O}_{3}+\mathrm{x}$ wt\% $\mathrm{Fe}_{2} \mathrm{O}_{3}$ ceramics (PZT-PZN-PMnN), where $x=0 \div 0.35$, has been prepared by two-stage calcination method. The effect of $\mathrm{Fe}_{2} \mathrm{O}_{3}$ content on the crystal structure and electrical properties of ceramics has been investigated. The results of X-ray diffraction (XRD) show that all samples have pure perovskite phase with tetragonal structure, the $c / a$ ratio increases with increasing $\mathrm{Fe}_{2} \mathrm{O}_{3}$ content. At $\mathrm{x}=0.25$, electrical properties of ceramics are best: the density $(\rho)$ of $7.86 \mathrm{~g} / \mathrm{cm}^{3}$, the electromechanical coupling factor $\left(k_{p}\right)$ of 0.64 , the dielectric constant $\left(\varepsilon_{r}\right)$ of 1400 , the dielectric loss $(\tan \delta)$ of 0.003 , the mechanical quality factor $\left(Q_{m}\right)$ of 1450 , the piezoelectric constant $\left(d_{31}\right)$ of $155 \mathrm{pC} / \mathrm{N}$, and the remanent polarization $\left(P_{r}\right)$ of $37 \mu \mathrm{C} / \mathrm{cm}^{2}$, which makes it as a promising material for high power piezoelectric devices.

\section{Keywords}

Crystal Structure, Dielectrics, Piezoelectrics, Electromechanical Coupling Factor, $\mathrm{Fe}_{2} \mathrm{O}_{3}$ Doping

\section{Introduction}

Relaxor ferroelectric materials have the high dielectric constant, broad ferroelectric-paraelectric transition (the diffuse phase transition) and strong frequency dependence of dielectric properties [1] [2]. So far, researchers have been interesting on the Pb-based relaxors $\mathrm{Pb}\left(\mathrm{B}_{1 / 3}^{\prime} \mathrm{B}_{2 / 3}^{\prime \prime}\right) \mathrm{O}_{3}$ because they are promising materials for multilayer capacitors, transducer and actuators [2]-[4].

The addition of small amounts of such relaxor materials was found to be beneficial for the electrical properties of PZT-based ceramics due to the formation of fine and uniform rhombohedral domains along tetragonal

"Corresponding author. 
ones [4] [5]. Recently, it was observed that both the dielectric and piezoelectric properties of these PZT-relaxor materials are strongly influenced by the addition of other additives such as $\mathrm{La}, \mathrm{ZnO}, \mathrm{CuO}, \mathrm{MnO}_{2}$ and $\mathrm{Fe}_{2} \mathrm{O}_{3}$ [2] [4] [6]-[8]. The $\mathrm{Fe}_{2} \mathrm{O}_{3}$ addition is probably one of the most frequently used acceptors in ferroelectrics. The effects of $\mathrm{Fe}_{2} \mathrm{O}_{3}$ on PZT and PZT-based ternary ceramics have been studied [7]-[10]. However, the effect of $\mathrm{Fe}_{2} \mathrm{O}_{3}$ addition on the quaternary PZT-PZN-PMnN was scarcely reported.

Recently, we studied the effect of $\mathrm{Zr} / \mathrm{Ti}$ ratio content on some physical properties of $0.8 \mathrm{~Pb}\left(\mathrm{Zr}_{\mathrm{x}} \mathrm{Ti}_{1-\mathrm{x}}\right) \mathrm{O}_{3}-$ $0.125 \mathrm{~Pb}\left(\mathrm{Zn}_{1 / 3} \mathrm{Nb}_{2 / 3}\right) \mathrm{O}_{3}-0.075 \mathrm{~Pb}\left(\mathrm{Mn}_{1 / 3} \mathrm{Nb}_{2 / 3}\right) \mathrm{O}_{3}$ [11]. We found that the electromechanical coupling factor $\left(k_{p}\right)$, the piezoelectric constant $\left(d_{31}\right)$ and the mechanical quality factor $\left(\mathrm{Q}_{\mathrm{m}}\right)$ of the ceramics are enhanced with the increase of $\mathrm{Zr} / \mathrm{Ti}$ ratio. At $\mathrm{Zr} / \mathrm{Ti}$ ratio of 48/52, the ceramics has the optimal electromechanical properties, $k_{p}=$ $0.62, d_{31}=140 \mathrm{pC} / \mathrm{N}, Q_{m}=1112$. According to our results [12] showed that $0.7 \mathrm{wt} \% \mathrm{Li}_{2} \mathrm{CO}_{3}$ was quite effective in lowering the sintering temperature of $0.8 \mathrm{PZT}-0.125 \mathrm{PZN}-0.075 \mathrm{PMnN}$ ceramics from $1150^{\circ} \mathrm{C}$ down to $930^{\circ} \mathrm{C}$, with the retention of good piezoelectric properties.

In this study, we investigated the effect of $\mathrm{Fe}_{2} \mathrm{O}_{3}$ doping on structure and electrical properties of $\mathrm{Fe}_{2} \mathrm{O}_{3}$-doped $0.8 \mathrm{~Pb}\left(\mathrm{Zr}_{0.48} \mathrm{Ti}_{0.52}\right) \mathrm{O}_{3}-0.125 \mathrm{~Pb}\left(\mathrm{Zn}_{1 / 3} \mathrm{Nb}_{2 / 3}\right) \mathrm{O}_{3}-0.075 \mathrm{~Pb}\left(\mathrm{Mn}_{1 / 3} \mathrm{Nb}_{2 / 3}\right) \mathrm{O}_{3}+0.7 \mathrm{wt} \% \mathrm{Li}_{2} \mathrm{CO}_{3}$ ceramics.

\section{Experimental Procedure}

The general formula of the studied material was $0.8 \mathrm{~Pb}\left(\mathrm{Zr}_{0.48} \mathrm{Ti}_{0.52}\right) \mathrm{O}_{3}-0.125 \mathrm{~Pb}\left(\mathrm{Zn}_{1 / 3} \mathrm{Nb}_{2 / 3}\right) \mathrm{O}_{3}-$ $0.075 \mathrm{~Pb}\left(\mathrm{Mn}_{1 / 3} \mathrm{Nb}_{2 / 3}\right) \mathrm{O}_{3}+0.7 \mathrm{wt} \% \mathrm{Li}_{2} \mathrm{CO}_{3}+\mathrm{x}$ wt $\% \mathrm{Fe}_{2} \mathrm{O}_{3}(\mathrm{PZT}-\mathrm{PZN}-\mathrm{PMnN})$, where $\mathrm{x}$ is $0,0.05,0.1,0.15,0.2$, $0.25,0.3,0.35$ and are denoted by $\mathrm{M}_{0}, \mathrm{M}_{1}, \mathrm{M}_{2}, \mathrm{M}_{3}, \mathrm{M}_{4}, \mathrm{M}_{5}, \mathrm{M}_{6}$, respectively. Reagent grade oxide powders (purity $\geq 99 \%$ ) of $\mathrm{PbO}, \mathrm{ZnO}, \mathrm{MnO}_{2}, \mathrm{Nb}_{2} \mathrm{O}_{5}, \mathrm{ZrO}_{2}, \mathrm{TiO}_{2}, \mathrm{Li}_{2} \mathrm{CO}_{3}$ and $\mathrm{Fe}_{2} \mathrm{O}_{3}$ were used as starting materials. Firstly, the powders of $(\mathrm{Zn}, \mathrm{Mn}, \mathrm{Fe}) \mathrm{Nb}_{2}(\mathrm{Zr}, \mathrm{Ti}) \mathrm{O}_{6}$ were prepared by reactions of $\mathrm{ZnO}, \mathrm{MnO}_{2}, \mathrm{Nb}_{2} \mathrm{O}_{5}, \mathrm{ZrO}_{2}, \mathrm{TiO}_{2}$ and $\mathrm{Fe}_{2} \mathrm{O}_{3}$ at temperature $1100^{\circ} \mathrm{C}$ for $2 \mathrm{~h}$. Then $(\mathrm{Zn}, \mathrm{Mn}, \mathrm{Fe}) \mathrm{Nb}_{2}(\mathrm{Zr}, \mathrm{Ti}) \mathrm{O}_{6}$ and $\mathrm{PbO}$ were weighed and milled for $8 \mathrm{~h}$. The powders were calcined at temperature $850^{\circ} \mathrm{C}$ for $2 \mathrm{~h}$, producing the PZT-PZN-PMnN compound. Thereafter, predetermined amounts of $\mathrm{Li}_{2} \mathrm{CO}_{3}$ were mixed with the calcined PZT-PZN-PMnN powder, and then, powders milled for $16 \mathrm{~h}$. The ground materials were pressed into disk $12 \mathrm{~mm}$ in diameter and $1.5 \mathrm{~mm}$ in thick under $100 \mathrm{MPa}$. The samples were sintered at $950^{\circ} \mathrm{C}$ for $2 \mathrm{~h}$.

The crystal structure of the sintered samples was examined by X-ray diffraction (XRD, D8 ADVANCE). The density of samples was measured by Archimedes method. The synthesized pellets were poled in a silicone oil bath at $120^{\circ} \mathrm{C}$ by applying the DC electric field of $30 \mathrm{kV} \cdot \mathrm{cm}^{-1}$ for 20 min then cooling down to room temperature (RT). They were aged for $24 \mathrm{~h}$ prior to testing.

The piezoelectric properties were determined with the resonance and antiresonance frequency using an impedance analyzer (HP 4193A and RLC HIOKI 3532). Dielectric measurements (capacitance and loss factor) were measured in the temperature range of 30 to $350^{\circ} \mathrm{C}$ at frequencies $1 \mathrm{kHz}$ by using a programmable temperature controller and an impedance analyzer (RLC HIOKI 3532).

\section{Results and Discussion}

\subsection{Effect of $\mathrm{Fe}_{2} \mathrm{O}_{3}$ Addition on the Structure and Microstructure of PZT-PZN-PMnN Ceramics}

Figure 1 shows X-ray diffraction patterns (XRD) of the PZT-PZN-PMnN ceramics at the different contents of $\mathrm{Fe}_{2} \mathrm{O}_{3}$. All samples have pure perovskite phase with tetragonal structure. When increasing of $\mathrm{Fe}_{2} \mathrm{O}_{3}$ content, the tetragonality c/a ratio increases as shown in Figure 2.

Figure 3 shows the SEM micrographs of the fracture surface of the samples as $\mathrm{Fe}_{2} \mathrm{O}_{3}$ addition. It is seen from the micrographs that the grain size grows with the increase of $\mathrm{Fe}_{2} \mathrm{O}_{3}$ addition (Figure 5). Below the $\mathrm{Fe}_{2} \mathrm{O}_{3}$ solubility of $0.25 \mathrm{wt} \%$, the grain sizes increase and the grain boundaries present regular shapes. However, when the addition of $\mathrm{Fe}_{2} \mathrm{O}_{3}$ is higher than $0.25 \mathrm{wt} \%$, a few cavities appeared between the grains.

Figure 4 shows the variation of density of PZT-PZN-PMnN samples at the different $\mathrm{Fe}_{2} \mathrm{O}_{3}$ contents. It can be seen that the density of the PZT-PZN-PMnN samples as a function of the $\mathrm{Fe}_{2} \mathrm{O}_{3}$ content. With $\mathrm{Fe}_{2} \mathrm{O}_{3}$ content increased, the density of PZT-PZN-PMnN samples increased. It achieves a maximum value $\left(\rho=7.86 \mathrm{~g} / \mathrm{cm}^{3}\right)$ at $\mathrm{Fe}_{2} \mathrm{O}_{3}$ content of $0.25 \mathrm{wt} \%$, and then decreases. The variation in density of the ceramic samples is in good accordance with the microstructure. When the addition is less than $0.25 \mathrm{wt} \%, \mathrm{Fe}^{3+}$ ions can incorporated into the perovskite and cause the increase of the density; however, the excess addition causes the aggregation at the grain 


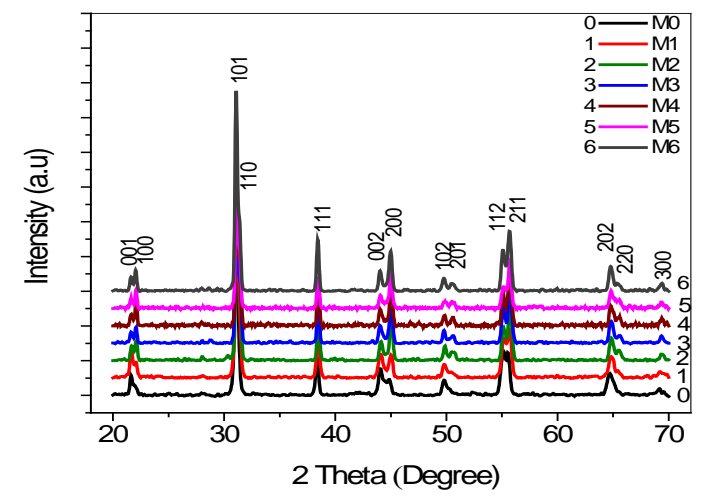

Figure 1. The XRD patterns of PZT-PZN-PMnN ceramics with different contents of $\mathrm{Fe}_{2} \mathrm{O}_{3}$.

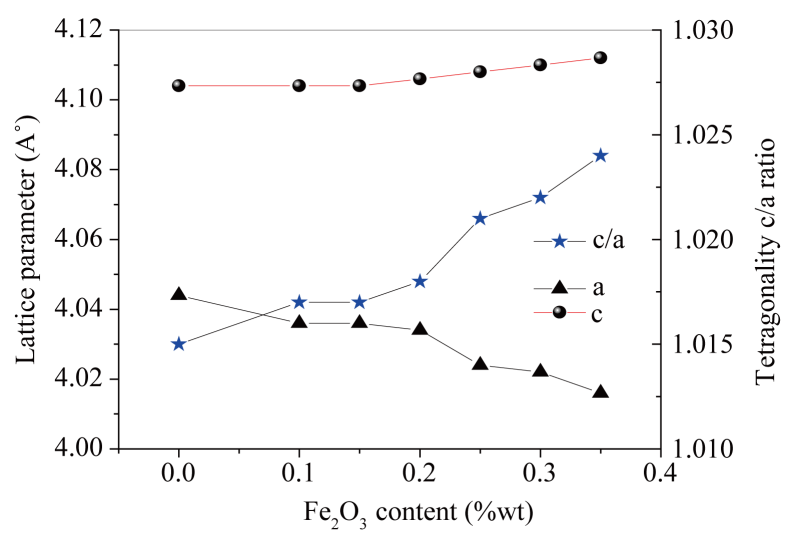

Figure 2. The lattice constant and the tetragonality c/a ratio of PZT-PZN-PMnN ceramics with different contents of $\mathrm{Fe}_{2} \mathrm{O}_{3}$.
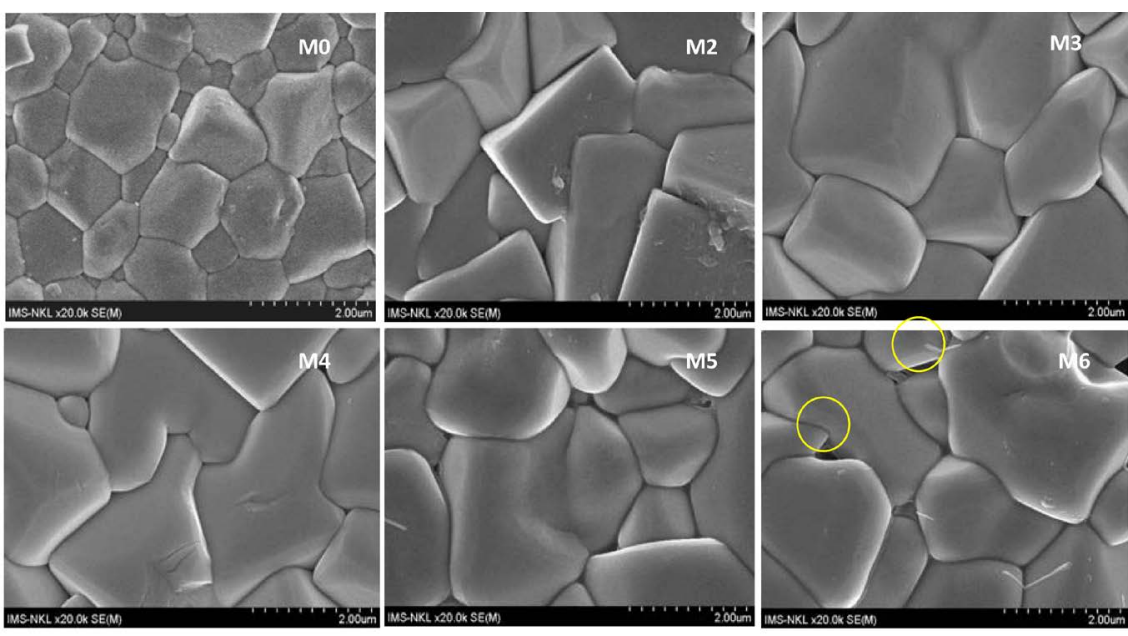

Figure 3. Microstructures of samples with the different $\mathrm{Fe}_{2} \mathrm{O}_{3}$ contents.

boundaries, thus leading to the decrease of the density of the samples [7] [8]. The variation in density may affirm the solubility limit of $\mathrm{Fe}_{2} \mathrm{O}_{3}$ in PZT-PZN-PMnN lattice.

The grain size, the density of ceramic have a strong effect on dielectric, piezoelectric and ferroelectric properties of ceramic materials. The relationships between the grain size and the density of ceramic and electrical properties are discussed in the next section. 


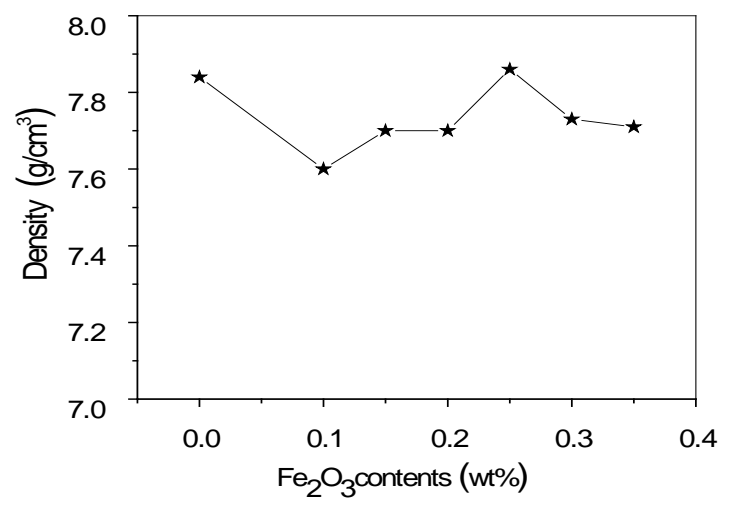

Figure 4. Density of the PZT-PZN-PMnN ceramics with different amounts of $\mathrm{Fe}_{2} \mathrm{O}_{3}$.

\subsection{Effect of $\mathrm{Fe}_{2} \mathrm{O}_{3}$ Content on the Electrical Properties of PZT-PZN-PMnN Ceramics}

Figure 5 shows the room temperature dielectric constant $\varepsilon_{r}$ at $1 \mathrm{kHz}$ of PZT-PZN-PMnN ceramics as function of the $\mathrm{Fe}_{2} \mathrm{O}_{3}$ contents. The $\varepsilon_{r}$ increases with the $\mathrm{Fe}_{2} \mathrm{O}_{3}$ content increases and reaches highest value $(1400)$ at $\mathrm{x}=$ 0.25 . With contents $\mathrm{x}>0.25$, the dielectric constant $\varepsilon_{r}$ decreased. This is related to grain size of ceramics. When the addition of $\mathrm{Fe}_{2} \mathrm{O}_{3}$ is lower than the solution limit, the drastic increase in grain size appears, which compensates for the effect of oxygen vacancy on pinning the motion of domains, thus leading to the increase of $\varepsilon_{r}$ [2] [6]-[8]. When the addition is above $0.25 \mathrm{wt} \%$, the occurrence of the cavities between the grains becomes obvious, which causes the decrease of the $\varepsilon_{r}[7]$ [8].

Figure 6 shows the forms of feroelectric hysteresis loops of the samples measured at room temperature. From the changes of the shape of these loops with $\mathrm{Fe}_{2} \mathrm{O}_{3}$ contents, the remanent polarization $P_{r}$ and the coercive field $E_{c}$ were determined, as shown in Figure 7. A sharp increase in $P_{r}$ was observed for $\mathrm{M}_{0}-\mathrm{M}_{4}$ samples, reaches the highest value (37 $\mu \mathrm{C} / \mathrm{cm}^{2}$ ) with M4 sample, and then decreases. This result is in good agreement with the studied dielectric and piezoelectric properties of the samples. While, the coercive field $E_{c}$ increases with increasing of $\mathrm{Fe}_{2} \mathrm{O}_{3}$ content. This results (increased $E c$ ) clearly indicate the "hard" characteristics with addition of $\mathrm{Fe}_{2} \mathrm{O}_{3}$, mainly caused by Fe ions substitution in $\mathrm{B}$ site leads to the creation of oxygen vacancies, which pin the movement of the ferroelectric domain walls [2] [7] [8].

To determine piezoelectric properties of ceramics, resonant vibration spectra of samples were measured at room temperature. From these resonant spectra, piezoelectric parameters of samples were determined. Figure 8 shows the electromechanical coupling factor $\left(k_{p}, k_{t}\right)$, the piezoelectric constant $\left(d_{31}\right)$, the mechanical quality factor $Q_{m}$ and dielectric loss $\tan \delta$ change as a function of the amount of $\mathrm{Fe}_{2} \mathrm{O}_{3}$. The mechanical quality factor $\left(Q_{m}\right)$ and the dielectric loss $(\tan \delta)$ of the $\mathrm{Fe}_{2} \mathrm{O}_{3}$-doped PZT-PZN-PMnN ceramics markedly improved, as shown in Figure 8. As the $\mathrm{Fe}_{2} \mathrm{O}_{3}$ content in the PZT-PZN-PMnN ceramics was increased up to 0.25 wt\%, the $\mathrm{Q}_{\mathrm{m}}$ value increased steadily up to 1450 while dielectric loss $\tan \delta$ decreased steadily down to the lowest value $(0.25 \%)$ because the Fe ions at the ( $\mathrm{Ti}, \mathrm{Zr}, \mathrm{Nb}$ ) sites in the lattice acted as acceptors. More specifically, the substitution of Fe ions in the B-sites of the perovskite structure increases the number of oxygen vacancies. As mentioned above, these oxygen vacancies induce a space charge and internal field inside the PZT-PZN-PMnN grains, which inhibits the motion of the domain walls, thereby increasing the $Q_{m}$ value and decreasing the $\tan \delta$ value [2] [7] [8] [10]. However, when the $\mathrm{Fe}_{2} \mathrm{O}_{3}$ content exceeded a certain threshold value ( $\left.>0.25 \mathrm{wt} \%\right)$, the $Q_{m}$ value decreased and the $\tan \delta$ value increased, apparently due to the solubility limit of Fe. When the amount of $\mathrm{Fe}_{2} \mathrm{O}_{3}$ added to PZT-PZN-PMnN ceramics exceeded the solubility limit, the excessive Fe ions could not incorporate into the lattice of perovskite structure, which accumulated at the grain boundaries and reduced the physical properties of ceramic materials [2] [7] [8]. As can be seen in Figure 8, the $k_{p}, k_{t}$ and the $d_{31}$ show a similar variation with increasing $\mathrm{Fe}_{2} \mathrm{O}_{3}$ content. When the content of $\mathrm{Fe}_{2} \mathrm{O}_{3}$ is lower than $0.25 \mathrm{wt} \%$, the $k_{p}$, $k_{t}$ and the $d_{31}$ are increased with increasing $\mathrm{Fe}_{2} \mathrm{O}_{3}$ content. The optimized values for $k_{p}$ of $0.64, k_{t}$ of 0.51 and $d_{31}$ of 155 pC/N were obtained at $\mathrm{x}=0.25$. This is probably related to characteristics of the increasing grain size. As is well known, the increased grain size makes domain reorientation easier and severely promotes domain wall motion, which could increase the piezoelectric properties [2] [7] [8] [11] [12]. 


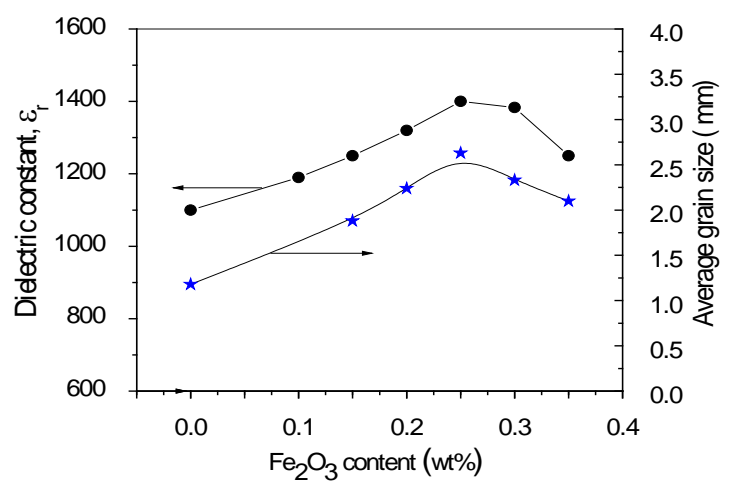

Figure 5. Room-temperature dielectric constant $\varepsilon_{r}$ and average grain size of ceramics with different amounts of $\mathrm{Fe}_{2} \mathrm{O}_{3}$.

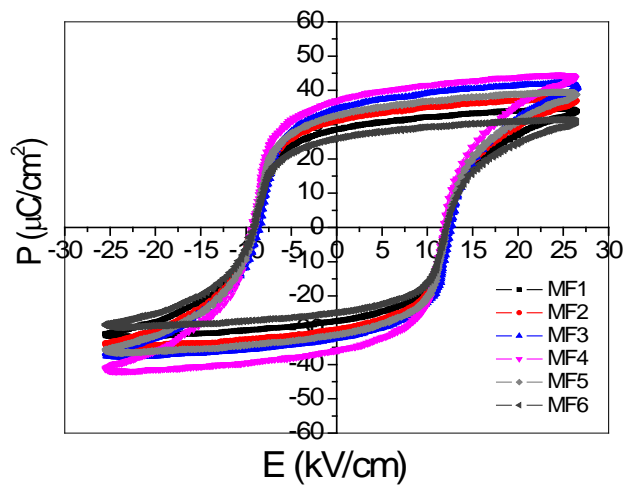

Figure 6. Hysteresis loops of $\mathrm{Fe}_{2} \mathrm{O}_{3}$-doped PZTPZN-PMnN ceramic samples.

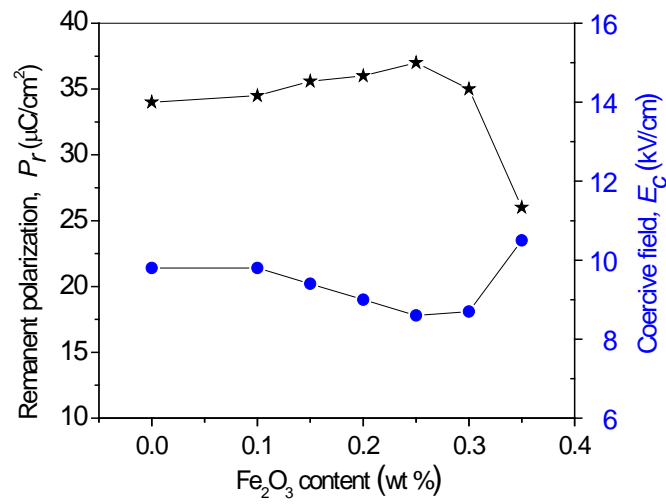

Figure 7. The $P_{r}$ and the $E_{c}$ as a function of $\mathrm{Fe}_{2} \mathrm{O}_{3}$ contents.

\section{Conclusions}

We have investigated the effect of $\mathrm{Fe}_{2} \mathrm{O}_{3}$ addition on structure and electrical properties of $0.8 \mathrm{~Pb}\left(\mathrm{Zr}_{0.48} \mathrm{Ti}_{0.52}\right)-$ $0.125 \mathrm{~Pb}\left(\mathrm{Zn}_{1 / 3} \mathrm{Nb}_{2 / 3}\right)-0.075 \mathrm{~Pb}\left(\mathrm{Mn}_{1 / 3} \mathrm{Nb}_{2 / 3}\right) \mathrm{O}_{3}$ ceramics. The results of this study are summarized as follow:

All samples have pure perovskite phase with tetragonal structure; the c/a ratio increases with increasing $\mathrm{Fe}_{2} \mathrm{O}_{3}$ contents.

The dielectric, piezoelectric and feroelectric properties of ceramics were markedly improved by $\mathrm{Fe}_{2} \mathrm{O}_{3}$ addition. At the $\mathrm{Fe}_{2} \mathrm{O}_{3}$ content of $0.25 \%$ wt, electrical properties of ceramics are best: the density of $7.86 \mathrm{~g} / \mathrm{cm}^{3}$, the 


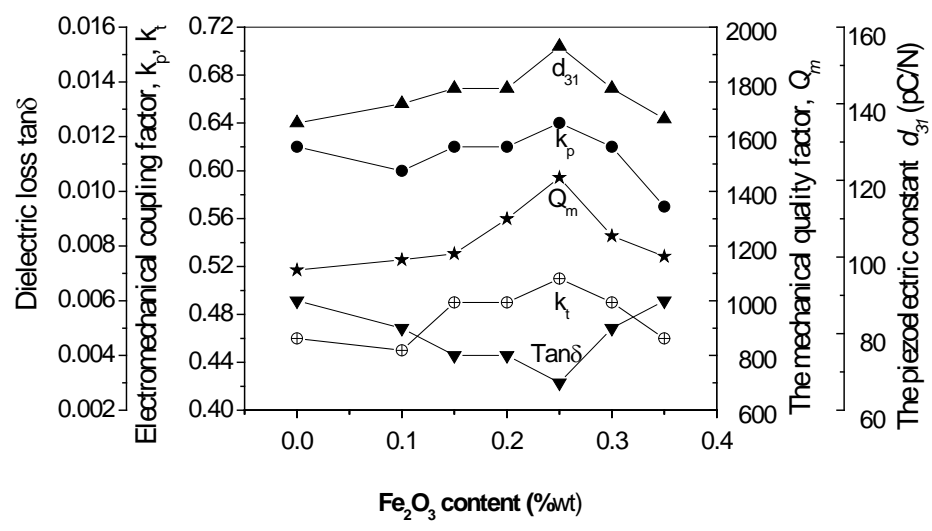

Figure 8. The $\mathrm{k}_{\mathrm{p}}, \mathrm{k}_{\mathrm{t}}, \mathrm{d}_{31}, \mathrm{Q}_{\mathrm{m}}$, and $\tan \delta$ as a function of $\mathrm{Fe}_{2} \mathrm{O}_{3}$ contents.

electromechanical coupling factor $\left(k_{p}\right)$ of 0.64 and $\left(k_{t}\right)$ of 0.51 , the dielectric constant, $\varepsilon_{r}$ of 1400 , the dielectric loss $(\tan \delta)$ of 0.003 , the mechanical quality factor $\left(Q_{m}\right)$ of 1450 , the piezoelectric constant $\left(d_{31}\right)$ of $155 \mathrm{pC} / \mathrm{N}$, and the remanent polarization $\left(P_{r}\right)$ of $37 \mu \mathrm{C} / \mathrm{cm}^{2}$, which makes it as a promising material for high power piezoelectric devices.

\section{References}

[1] Fan, H. and Kim, H. (2002) Journal of Applied Physics, 91, 317-322. http://dx.doi.org/10.1063/1.1421036

[2] Xu, Y. (1991) Ferroelctric Materials and Their Applications (North-Holland, Amsterdam-London-Newyork-Tokyo).

[3] Seo, S.B., Lee, S.H., Yoon, C.B., Park, G.T. and Kim, H.E. (2004) Journal of the American Ceramic Society, 87, 12381243. http://dx.doi.org/10.1111/j.1551-2916.2004.tb20095.X

[4] Yan, Y.K., Kumar, A., Correa, M., Cho, K.-H., Katiyar, R.S. and Priya, S. (2012) Applied Physics Letters, 100, Article ID: 152902. http://dx.doi.org/10.1063/1.3703124

[5] Gao, F., Cheng, L., Hong, R., Liu, J., Wang, C. and Tian, C. (2009) Ceramics International, 35, 1719-1723.

[6] Kim, Y.H., Ryu, H., Cho, Y.-K., Lee, H.-J. and Nahm, S. (2013) Journal of the American Ceramic Society, 96, 31-317. http://dx.doi.org/10.1111/j.1551-2916.2012.05461.X

[7] Zhu, M.K., Lu, P.X., Hou, Y.D., Wang, H. and Yan, H. (2005) Journal of Materials Research, 20, 2670-2675. http://dx.doi.org/10.1557/JMR.2005.0339

[8] Zhu, M.K., Lu, P.X., Hou, Y.D., Song, X.M., Wang, H. and Yan, H. (2006) Journal of the American Ceramic Society, 89, 3739-3744. http://dx.doi.org/10.1111/j.1551-2916.2006.01281.X

[9] Li, J., He, Z.B. and Damjanovic, D. (2009) Applied Physics Letters, 95, Article ID: 012905. http://dx.doi.org/10.1063/1.3173198

[10] Du, J., Qiu, J., Zhu, K., et al. (2012) Journal of Materials Letters, 66, 507-510.

[11] L.D. Vuong, Gio, P.D., Chuong, T.G.V., Trang, D.T.H., Hung, D.V. and Duong, N.T. (2013) International Journal of Materials and Chemistry, 3, 39-43.

[12] Vuong, L.D. and Gio, P.D. (2013) International Journal of Materials Science and Applications, 2, 89-93. 
Scientific Research Publishing (SCIRP) is one of the largest Open Access journal publishers. It is currently publishing more than 200 open access, online, peer-reviewed journals covering a wide range of academic disciplines. SCIRP serves the worldwide academic communities and contributes to the progress and application of science with its publication.

Other selected journals from SCIRP are listed as below. Submit your manuscript to us via either submit@scirp.org or Online Submission Portal.
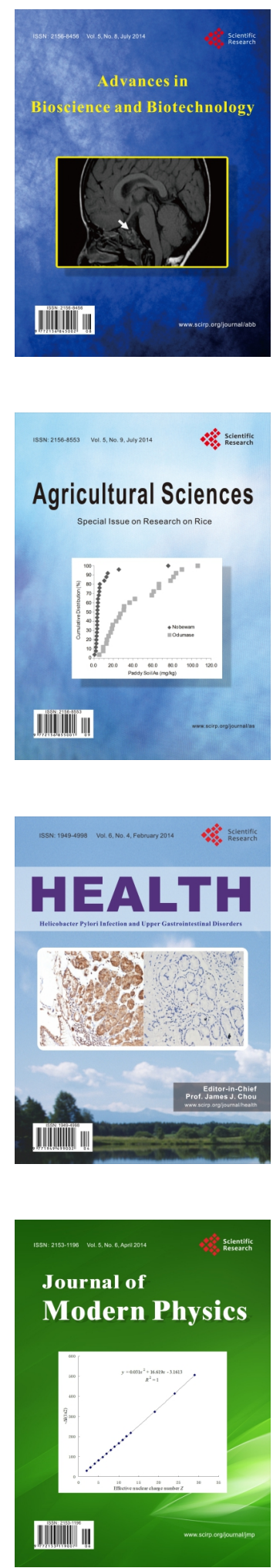
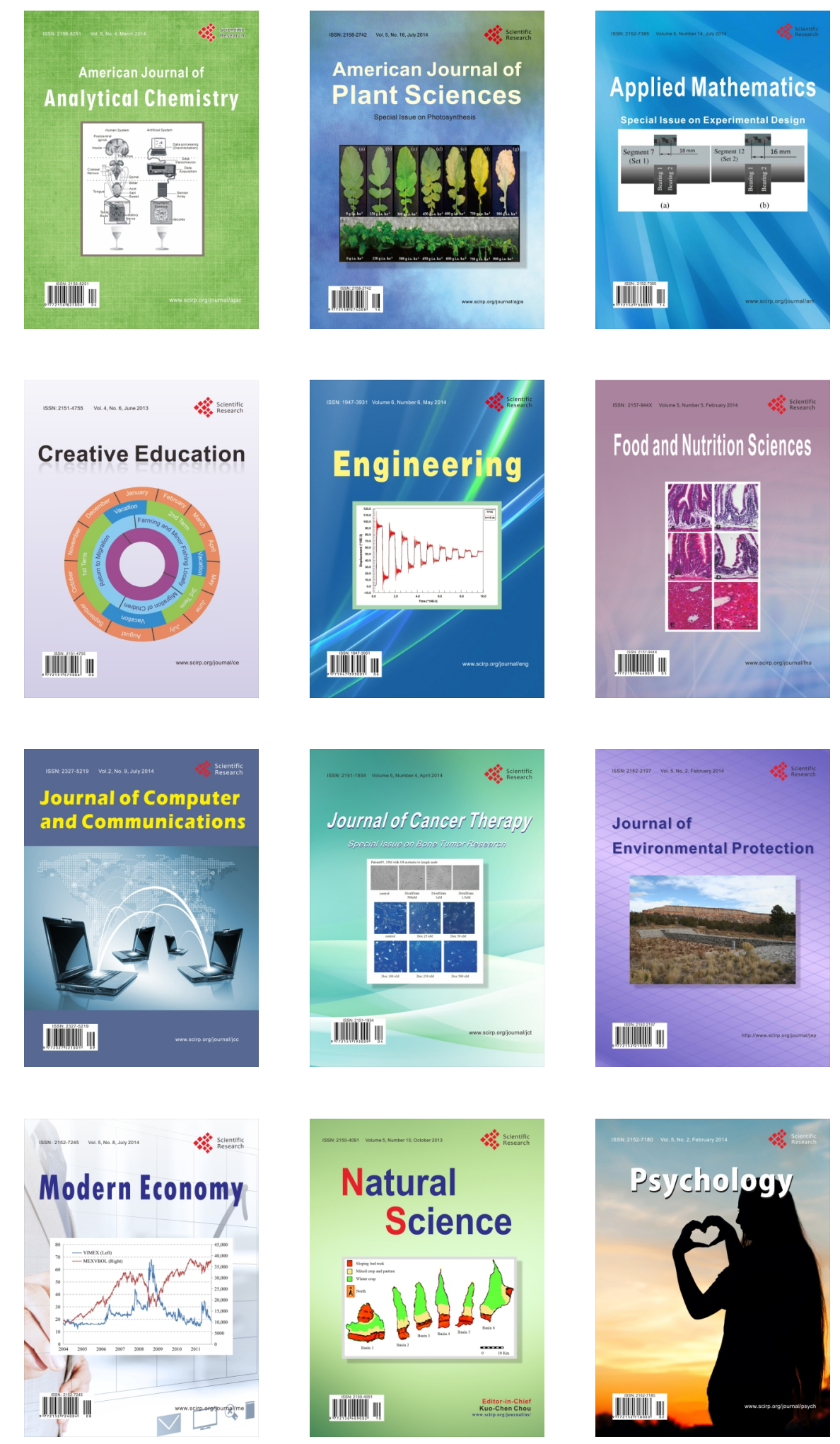